Manifestly if one was a variety of the other there should be no difference in the season of appearing.

The late Judge Truman, of South Dakota, took both species at Volga. He was satisfied that they were distinct, and gave the same reasons as cited above for his belief.

Here at Louisiana we take a few abbreviatella nearly every year, but have found no Whitneyi.

In the large number of specimens of both forms that we have taken during the last twenty years or more we have never found an intergrade, nor have we observed any variation of either form toward the other.

Nothing short of breeding one or both in confinement can definitely settle the question and prove or disprove their identity.

But if we array the facts as above stated against the bare assertion that "they look somewhat alike," the preponderance of proof seems to favor the contention that they are distinct.

If anyone has established the identity of these two forms we have overlooked it.

Prof. French, in his revision of the Catocalæ, published in this journal, rated both residua and Whitneyi as species, and they so appear in Dyar's Catalogue, which adopts his classification.

But Prof. French carefully consulted every available source of information before passing upon the validity of a species. As the years go by the intrinsic value of his work will be made manifest.

SOME NEW SPECIES OF PARASITLC HYMENOPTERA.

BY CHARLES T. BRUES, AMERICAN MUSEUM OF NATURAL HISTORY, NEW YORK CITY.

Dryinus nigrellus, sp. nov.-Female. Length $4.25 \mathrm{~mm}$. Wholly black, except tarsi, part of antennæ and mandibles. Head black, finely rugulose, faintly silvery pubescent and sub-shining. Vertex impressed; front with a short median impressed groove above the antennæ. Cheeks roughened; mandibles pale yellow, with the tip of the teeth black; quadridentate, the outer tooth the larger and the inner one extremely minute; palpi black. Antennæ filiform, reaching to the base of the abdomen, ten-jointed; first three joints and base of fourth rufous, remainder black, except the last, which is pale yellow. Scape stout, slightly over twice as long as the pedicel ; first flagellar joint twice as long as the scape, remaining joints decreasing in length, except the last, which is one and 
one-half times as long as the penultimate. Pronotum ovoid, finely rugulose, with a transverse depression at anterior third; behind this very sharply convex; two and one-half times as long as the mesonotum and one-half as wide as the head. Mesonotum more coarsely sculptured than the pronotum, twice as wide as long, tegulæ piceous; scutellum large, finely rugulose, with a punctate frenum anteriorly. Metanotum slightly longer than the pronotum, rounded behind; rather finely and evenly longitudinally rugoso-aciculate. Abdomen ovate, black, highly polished, extreme tip rufous. Petiole shorter than the hind coxa; second, third and fourth segments about equai, the fifth somewhat longer. Legs piceous black, the swollen femora below and the knees reddish. Anterior tibiæ and their metatarsi fuscous, the tarsi chelate, rufous; four posterior tarsi pale yellow. Wings hyaline, marked with two fuscous spots; the first fills out the two basal cells, except their extreme bases, and the second covers the stigma and stigmatal vein, fading out posteriorly. Basal cells very distinct, marginal cell not complete; stigma of moderate size.

Described from a single female specimen collected at Parkville, Long Island, by Mr. Wm. Beutenmuller. Type in the collection of the American Museum of Natural History.

This species can be most readily recognized by its very dark coloration.

Bocchus atriceps, sp. nov.-Female. Length, $5 \mathrm{~mm}$. Rufous, head and posterior portion of abdomen black. Head black, shining; rufous below the base of the antennæ; front coarsely rugulosely punctate above, below irregularly longitudinally striate : occiput margined; cheeks finely punctate and clothed with delicate white hairs; mandibles light yellow; maxillary palpi four-jointed, fuscous, joints nearly equal. Antenna slender, reaching to the base of the hind coxæ; ten-jointed; four basal joints rufous, others black; scape short, stout, a little longer than the slender pedicel; both together equal to the long, slender first flagellar joint; second flagellar joint two-thirds as long as the first; others slightly decreasing in length to apex. Prothorax half as wide as head, a little longer than wide, constricted just before the apex; rufous, white pubescent on the sides. Mesonotum distinctly shorter than the pronotum, the two furrows deep; surface shining, rufous medially, fuscous on the sides. Scutellum semi-circular, separated from the mesonotum and post-scutellum by transverse furrows. Metathorax short, rounded behind, coarsely reticulate; rufous, except the anterior edge, which is black. 
Abdomen ovate, polished, short petiolate, black, except the greater part of the first segment and the extreme tip, which are black; second, third and fourth segments sub-equal in length. Legs rufous, the tarsi lighter; femora, especially the anterior pair, very stout; anterior tarsi chelate, first joint long; anterior femora with a black mark below at the base, tips of posterior femora and tibie also black. Wings hyaline, with a fuscous band just beyond the stigma, also a faint fuscous spot at the apex of the second basal cell, stigma lanceolate.

Described from a single female specimen collected at Mosholu, N.Y., July 25,1903 , by Mr. J. R. de la Torre Bueno.

This species may be distinguished from the only other described species of Bocchus (B. favicollis, Ashm.) by its colour, larger size, different length of abdominal segments and configuration of the antennæ. It agrees very well with the generic diagnosis given by Ashmead (Monog. Proctotrypidæe, p. 91).

Oxylabis bifoveolatus, sp. nov.-Male. Length, $3 \mathrm{~mm}$. Black; legs fuscous, varied with rufous. Head shining black, rugulose on the occiput, with a short impressed longitudinal line above the ocelli; head margined behind ; cheeks shagreened; mandibles dark fuscous. Antenux I 4-jointed, distinctly longer than the body, tapering toward the tips ; two basal joints black, the rest fuscous. Scape very short, twice as long as the pedicel, which is less than one-half as long as the first flagellar joint; first eleven flagellar joints of equal length, the last one and one-half times as long as the preceding and more slender. Sides of the pronotum coarsely and obliquely striate. Mesonotum with two deep furrows, less pronounced anteriorly, and with a triangular fovea just before the scutellum. Scutellum with two deep fovex. Post-scutellum with a median groove and a more delicate one on each side; its tip produced into a long, acute black spine, which is perpendicular to the posterior face of the metathorax. Metanotum anteriorly coarsely rugose-striate, at the middle with a widely-interrupted transverse furrow, behind this with a fovea on each side, and medially at the tip with a large enclosed space. Petiole on abdomen suddenly constricted in front, a little wider than long and coarsely fluted. Remainder of abdomen compressed and very shining, impunctate; second segment very long, others short. Legs fuscous; front tibia, knees and bases of the tarsi lighter. Wings 
hyaline, basal and marginal cells complete; the latter completely closed, one and one-half times as long as high, and with the stump of a vein at its lower angle.

Described from a single specimen from Snake Hill, New Jersey; collected in June by Mr. Wm. Beutenmuller. Type in the collection of the American Museum of Natural History.

This species can be easily distinguished from O. spinosus, Ashm., the only other described North American species, by its bifoveate scutellum, and straight, black, post-scutellar spine.

\section{ON THE GENUS PROTEOPTERYX.}

BY PROF. C. H. FERNALD, AMHERST, MASS.

This genus was established by Lord Waisingham in Illustrations of Typical Specimens of Lepidoptera Heterocera in the collection of the British Museum, Part IV., North American Tortricidæ, p. 68 (i 879), with emarginana, Wlsm., the only species under it. This variable species was taken in Mendocino and Jake Counties, California, in considerable numbers (about 40 specimens) in June, $187 \mathrm{I}$, and five varieties were described. His Lordship had the great kindness to give me several examples representing the different varieties.

The generic characters, as given in the original description, need some revision, which the author would doubtless have given before this time if he had had occasion to review the genus. There is a costal fold in the three male specimens of this species in my collection, which character the author overlooked, as it is generally so closely pressed to the surface of the wing as to be scarcely visible, but in one of my specimens the fold on one wing is turned up sufficiently to expose the usual pencil of long hairs. Veins 7 and 8 of the fore wings are said to be "scarcely separate at their origin," which is true in my examples of this species, but in some allied species belonging to this genus these veins arise near each other, or are connate, or stalked, or sometimes connate in one wing and stalked in the other of the same specimen. Vein 5 in the hind wing is bent down, and has its origin near that of the stem of 3 and 4, which are stalked. The European species, crenana, Hub., belongs to this genus. 